\title{
Pengembangan Media Kartu Bergambar Berorientasi Pendidikan Karakter Pada Mata Pelajaran Bahasa Bali
}

\author{
Dewa Made Adi Andhika Nida \\ Program Studi Teknologi Pendidikan, Universitas Pendidikan Ganesha \\ dewa.made.adi@undiksha.ac.id \\ Desak Putu Parmiti \\ Program Studi Teknologi Pendidikan, Universitas Pendidikan Ganesha \\ dp-parmiti@undiksha.ac.id
}

Adrianus I Wayan Ilia Yuda Sukmana

Program Studi Teknologi Pendidikan, Universitas Pendidikan Ganesha aiwiy-sukmana@undiksha.ac.id

\author{
A R T I C L E I N F O \\ Article history: \\ 1 Januari 2020 Received in \\ revised form \\ 30 Mei 2020 \\ Accepted 30 Juni 2020 \\ Available online \\ 15 Juli 2020

\section{Kata Kunci:} \\ media kartu bergambar, \\ pendidikan karakter \\ Keywords: \\ picture card media, \\ character education
}

\begin{abstract}
ABSTRAK
Dilaksanakannya penelitian pengembangan ini pada dasarnya dilatarbelakangi oleh rendahnya hasil belajar Bahasa Bali siswa yang disebabkan oleh kurangnya media pembelajaran yang relevan. Tujuan dari penelitian ini yaitu untuk mendeskripsikan rancang bangun media kartu bergambar berorientasi pendidikan karakter, mendeskripsikan hasil uji validasi media kartu bergambar berorientasi pendidikan karakter, serta mengetahui efektivitas penerapan media kartu bergambarberorientasi pendidikan karakter. Model yang digunakan dalam penelitian pengembangan ini adalah model ADDIE. Data dikumpulkan dengan metode pencatatan dokumen,
\end{abstract} kuesioner, wawancara, dan tes tertulis. Hasil uji validasi yang dilakukan oleh para ahli dan kelompok mahasiswa subyek uji coba produk menunjukkan bahwa media kartu bergambar dinyatakan valid dengan rincian hasil yaitu: ahli mata pelajaran 100\%, ahli desain pembelajaran $95,71 \%$, ahli media pembelajaran $95,00 \%$, uji coba perorangan $97,33 \%$, uji coba kelompok kecil 97,55\%, dan uji lapangan 98,00\% dengan kualifikasi sangat baik. Berdasarkan uji efektifitas yang telah dilakukan menunjukkan bahwa media kartu bergambar berorientasi pendidikan karakter terbukti efektif meningkatkan hasil belajar Bahasa Bali siswa.

\begin{abstract}
This research development is basically motivated by the low student learning outcomes of Balinese caused by the lack of relevant learning media. The purpose of this study aim to describe the design of character education oriented picture cards media, describe the results of the validation test of character education oriented picture cards media, and find out the effectiveness of the application of character education oriented picture cards media. The model that used in this research development was the ADDIE model. Data was collected by the method of recording documents, questionnaires, interviews, and written tests. The results of the validation test conducted by experts and group of students that subjecting to product trials shows that this picture cards media is valid with detailed results: $100 \%$ by subject matter expert, $95.71 \%$ by learning design expert, $95.00 \%$ by learning media expert, $97.33 \%$ by individual subject trials, $97.55 \%$ by small group subject trials, and $98.00 \%$ by field test subject which is very good qualifications. Based on the effectiveness test that has been done
\end{abstract}


shows that the character education oriented picture cards media is proven to be effective in increasing student learning outcomes in Balinese.

\section{PENDAHULUAN}

Kualitas pendidikan bergantung pada proses pembelajaran yang efektif dan efisien, yang dapat memotivasi siswa untuk belajar. Peran pendidik sangat penting untuk mewujudkan pembelajaran yang efektif dan efesien. Pendidik sering sekali kurang tanggap terhadap perkembangan pendidikan dalam hal ketersediaan media pembelajaran dan bahan ajar di sekolah, pembelajaran masih terpusat pada guru, kurangnya mengintegrasikan kearah pembentukan karakter siswa. Kurangnya ketersediaan media pembelajaran di sekolah, salah satu bentuk sumber belajar yang seharusnya ada untuk kepentingan belajar peserta didik. Kelengkapan sarana dan prasarana di sekolah, sangat berperan dalam ketersediaan bahan ajar tersebut. Berkaitan dengan hal tersebut, ketersediaan media pembelajaran sangat diperlukan dalam menunjang proses pembelajaran. Media merupakan salah satu komponen yang sangat penting dalam proses pembelajaran. Asyhar (2012) berpendapat bahwa "Media adalah perantara atau pengantar pesan dari pengirim (komunikator atau sumber/source) kepada penerima (komunikan atau audience/receiver)". Media mempunyai peranan sangat penting dalam menyampaikan materi dalam proses pembelajaran serta sebagai sarana komunikasi guna menyampaikan pesan dalam proses pembelajaran. "Media pembelajaran juga harus dikembangkan oleh seorang guru untuk mempermudah dalam menyampaikan materi” (Mardati \& Wangit, 2015:121). Selain itu, media memiliki peran penting dalam menumbuhkan nilai-nilai pendidikan karakter pada diri siswa.

Karakter merupakan salah satu ciri khas dalam diri manusia, yang meliputi akhlak, moral, dan budi pekerti. Zubaedi (2011) berpendapat bahwasannya "di era globalisasi saat ini terjadi krisis yang sangat mengkhawatirkan berkaitan dengan pendidikan karakter, dalam hal ini melibatkan masyarakat dan anak-anak". Merujuk hal tersebut, pembelajaran pendidikan karakter sangatlah diperlukan. Dimana Setiawati (2017:348) berpendapat bahwa "Pendidikan karakter merupakan suatu hal yang sangat penting dalam membangun bangsa yang beradab dan bermartabat, baik di mata Tuhan, dunia Internasional, dan manusia". Tugas dari pendidikan, adalah membuat peserta didik menjadi berkarakter.

Karakter yang baik tercermin dari nilai-nilai pancasila. Creasy (dalam Zubaedi, 2011:16) berpendapat bahwa "Pendidikan karakter sebagai upaya mendorong peserta didik tumbuh dan berkembang dengan kompetensi berpikir dan berpegang teguh pada prinsipprinsip moral dalam hidupnya serta mempunyai keberanian melakukan yang benar, meskipun dihadapkan pada berbagai tantangan". Pendidikan karakter memiliki tujuan untuk mengembangkan karakter peserta didik agar dapat mewujudkan nilai-nilai yang terkandung dalam pancasila. Alwis (dalam Setiawati, 2017) berpendapat bahwasannya "pendidikan karakter memiliki fungsi sebagai pengembangan potensi dasar agar berhati baik, berpikiran baik, dan berperilaku baik, sesuai dengan nilai-nilai luhur pancasila".

Namun kenyataannya, penurunan kualitas karakter dalam diri siswa seperti tindakan melanggar disiplin, menyontek pekerjaan teman, dan lain sebagainya tetap terjadi. Karena pendidikan cenderung lebih menitikberatkan pada hal pengembangan kognitif, tanpa diimbagi dengan pengembangan soft skills. Berkaitan dengan hal tersebut pendidikan karakter diharapkan dapat memberikan penekanan pada diri peserta didik seperti rasa hormat, tanggungjawab, peduli, jujur, adil serta dapat membantu peserta didik dalam 
memahami, memperhatikan, serta mampu menerapkan nilai-nilai tersebut kedalam kehidupan mereka, namun saat ini karakter pada siswa sudah mulai terkikis oleh arus globalisasi. Pesatnya globalisasi berdampak negatif terhadap kebanggaan para generasi muda pada tradisi budaya itu sendiri. Hal ini terlihat jelas pada kemampuan menulis dan memahami Aksara Bali. "Bahasa Bali merupakan suatu ilmu tata wicara/berbicara (bahasa daerah) yang memiliki sistematika pelafalan, dan sebagai alat komunikasi bagi masyarakat Bali” (Pradipta \& Darmawiguna, 2015:3). Pertama, dkk (2015) berpendapat bahwa "Aksara Bali sangat penting dalam menanamkan nilai kebudayaan bagi generasi muda sebagai generasi penerus, hal tersebut sehubungan dengan banyaknya peninggalan nenek moyang berupa tulisan aksara Bali yang harus dilestarikan. I Nengah Duija (dalam Sujana, 2017:49) berpendapat bahwa "bahasa Bali memiliki tingkatan yang digunakan sebagai alat komunikasi". "Pembelajaran sor singgih bahasa Bali sangat berperan aktif, sebagai upaya untuk melestarikan bahasa Bali di era globalisasi” (Sujana, 2017:49).

Sehubungan dengan hal tersebut, maka nilai-nilai yang tercermin dalam pendidikan karakter tentunya dapat diterapkan pada muatan Bahasa Bali. Mengingat "mata pelajaran Bahasa Bali merupakan salah satu pelajaran wajib di Provinsi Bali yang diajarkan pada semua jenjang pendidikan dasar dan menengah" (Martini, dkk, 2018:75).

Berdasarkan pemaparan permasalahan di atas, salah satu solusi yang dapat digunakan untuk mengembangkan media pembelajaran yaitu dengan menggunakan media kartu bergambar berorientasi pendidikan karakter. Media pembelajaran kartu bergambar berorientasi pendidikan karakter ini, dirancang dan didesain untuk memudahkan siswa dalam proses pembelajaran, dikarenakan siswa akan dibagi menjadi beberapa kelompok, kemudian siswa akan diajak bermain kartu untuk menjawab pertanyaan-pertanyaan yang ada pada kartu bergambar, dengan demikian media kartu bergambar ini dapat menarik minat siswa untuk belajar dan meningkatkan hasil belajar siswa. Di samping itu, dengan media ini akan memudahkan guru dalam menyampaikan materi pembelajaran. Penelitian pengembangan ini didukung oleh penelitian yang sudah ada sebelumnya, penelitian tersebut antara lain, Penelitian yang dilakukan oleh Rahayu, dkk (2017) menunjukkan bahwa pelaksanaan pendidikan karakter melalui penerapan budaya $5 \mathrm{~S}$ di sekolah telah terbukti efektif, yang dapat menghasilkan penanaman nilai-nilai karakter, penelitian tersebut sejalan dengan penelitian yang dilakukan oleh Hidayati, dkk (2014) menemukan bahwa penelitian ini bertujuan untuk menghasilkan kurikulum pendidikan karakter yang valid dengan menggunakan media, penelitian ini sejalan dengan penelitian yang dilakukan oleh Jamuna \& Pankajam (2017) menemukan bahwa para guru harus didorong untuk menggunakan media pembelajaran dalam proses belajar mengajar.

Penggunaan media kartu bergambar berorientasi pendidikan karakter ini, diharapkan dapat meningkatkan ketuntasan dalam pembelajaran kelas III di SD Negeri 4 Kaliuntu, khususnya dalam pembelajaran Bahasa Bali. Penelitian ini bertujuan untuk mengembangkan sebuah media berbentuk Permainan Edukatif, yang diintegrasikan dengan pendidikan karakter untuk siswa. Suyadi (dalam Ariyanti \& Zidni, 2015:60) berpendapat bahwa "permainan edukatif dirancang secara multiguna, sehingga anak dapat mengenal konsep warna, bentuk dan ukuran". Permainan edukatif juga merupakan "suatu kegiatan yang bersifat mendidik" (Hijriati, 2017). "Permainan kartu bergambar merupakan salah satu permainan yang dapat digunakan dalam proses pembelajaran (Meiliani, 2017:49).

Prasetya \& Khabibah (2016) berpendapat bahwa "media permainan kartu bergambar merupakan salah satu jenis pengembangan media cetak berbasis visual". Media 
pembelajaran kartu bergambar berorientasi pendidikan karakter ini, dirancang dan didesain untuk memudahkan siswa dalam proses pembelajaran, dikarenakan siswa akan dibagi menjadi beberapa kelompok, kemudian siswa akan diajak bermain kartu untuk menjawab pertanyaan-pertanyaan yang ada pada kartu bergambar, dengan demikian media kartu bergambar ini dapat menarik minat siswa untuk belajar dan meningkatkan hasil belajar siswa.

\section{METODE PENELITIAN}

Penelitian ini dilaksanakan pada tanggal 27 Maret 2019 sampai 8 Januari 2020. Populasi dalam penelitian ini adalah seluruh siswa kelas III di SDN 4 Kaliuntu dengan jumlah 30 orang siswa. Prosedur pengembangan mengacu pada lima tahapan model ADDIE. Tegeh, dkk (2015) menjelaskan "lima tahapan model ADDIE meliputi: (1) Tahap Analisis (Analyze), (2) Tahap Perancangan (Design), (3) Tahap Pengembangan (Development), (4) Tahap Implementasi (Implementation), (5) Tahap Evaluasi (Evaluation)".

Pengumpulan data dalam penelitian ini yakni menggunakan metode pencatatan dokumen, kuesioner, wawancara, dan tes tertulis. (1) Kuesioner digunakan saat analisis kebutuhan, review ahli isi pembelajaran, ahli desain pembelajaran, serta ahli media pembelajaran, (2) Wawancara bertujuan guna mengetahui permasalahan yang terjadi dalam pembelajaran di lapangan, (3) Pencatatan dokumen bertujuan guna mengumpulkan data mengenai rancang bangun pengembangan media berdasarkan wawancara bersama guru mata pelajaran Bahasa Bali SDN 4 Kaliuntu Tahun Pelajaran 2019/2020, dan (4) Metode tes digunakan untuk menggali data hasil belajar. Instrumen tes yang digunakan yakni tipe pilihan ganda (multiple choice) serta tipe bentuk melengkapi (completion). Pengumpulan data dalam penelitian ini menggunakan beberapa instrumen yakni (1) lembar kuesioner, (2) lembar pedoman wawancara, (3) lembar pencatatan dokumen, serta (4) lembar tes tertulis pretest dan postest.

Tabel 1. Kisi-Kisi Instrumen Review Ahli Isi Mata Pelajaran

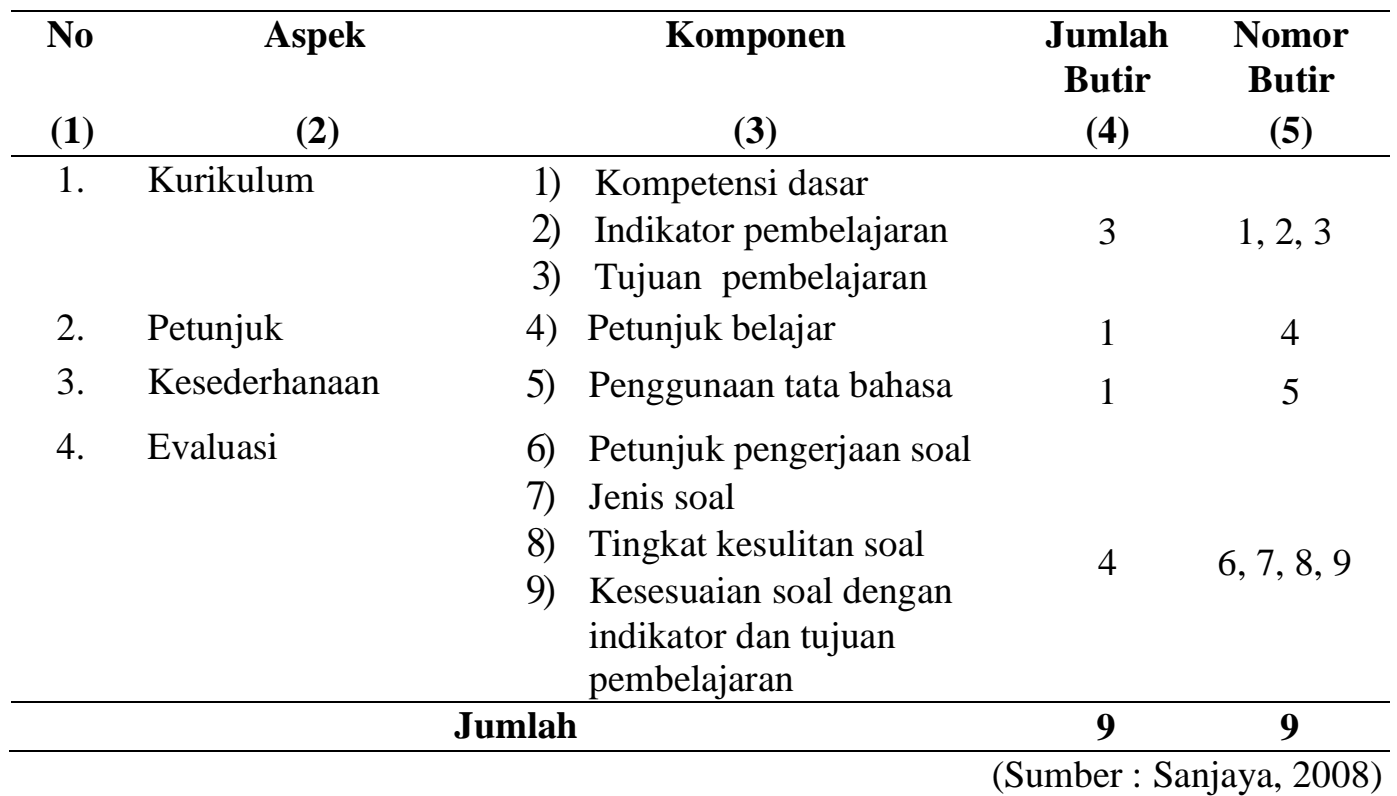


Tabel 2. Kisi-Kisi Instrumen Review Ahli Desain Pembelajaran

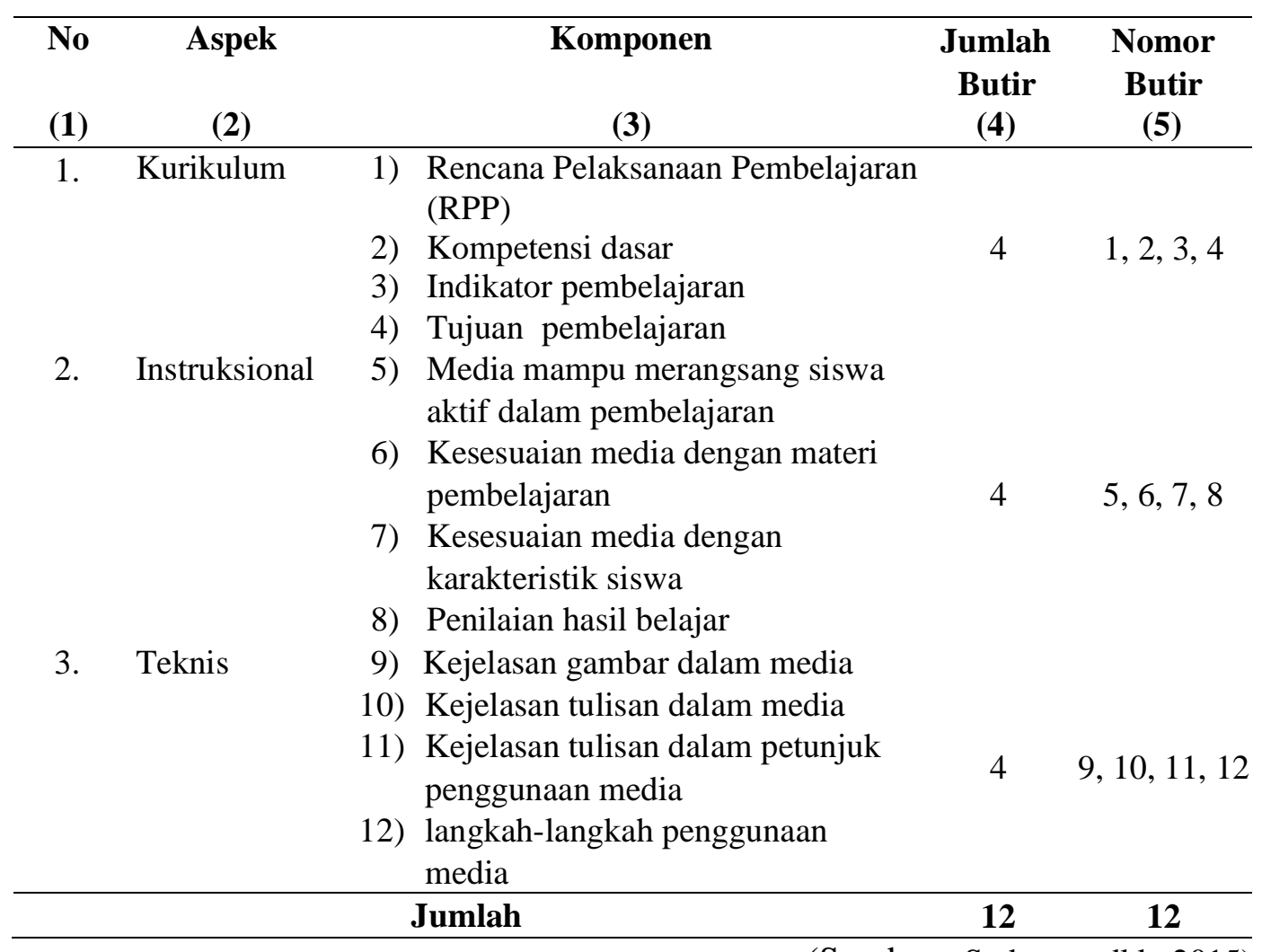

(Sumber : Sudarma, dkk, 2015)

Tabel 3. Kisi-Kisi Instrumen Review Ahli Media Pembelajaran

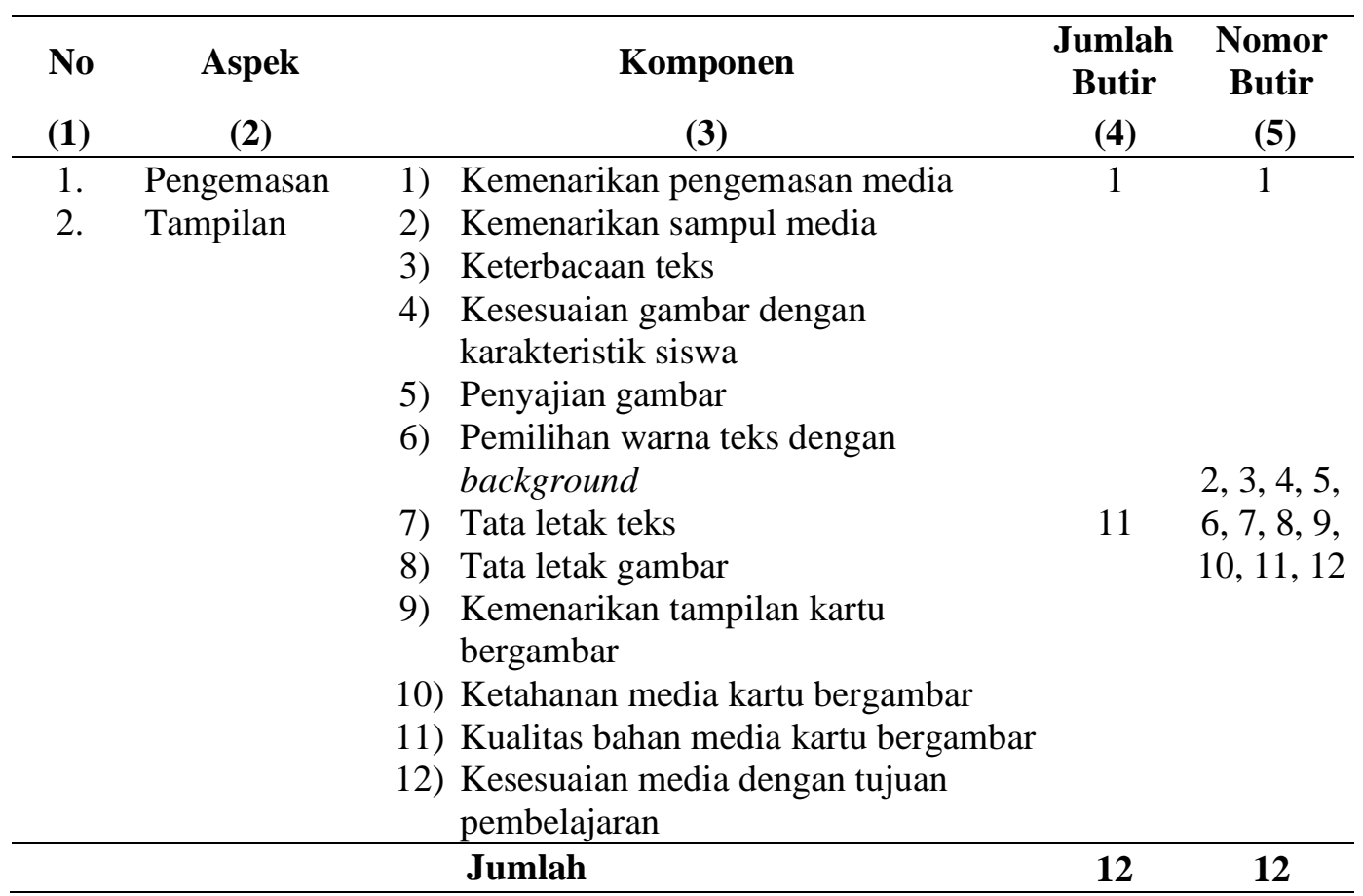

(Sumber : Sudarma, dkk, 2015) 
Tabel 4. Kisi-Kisi Instrumen Review Uji Coba Perorangan dan Kelompok Kecil

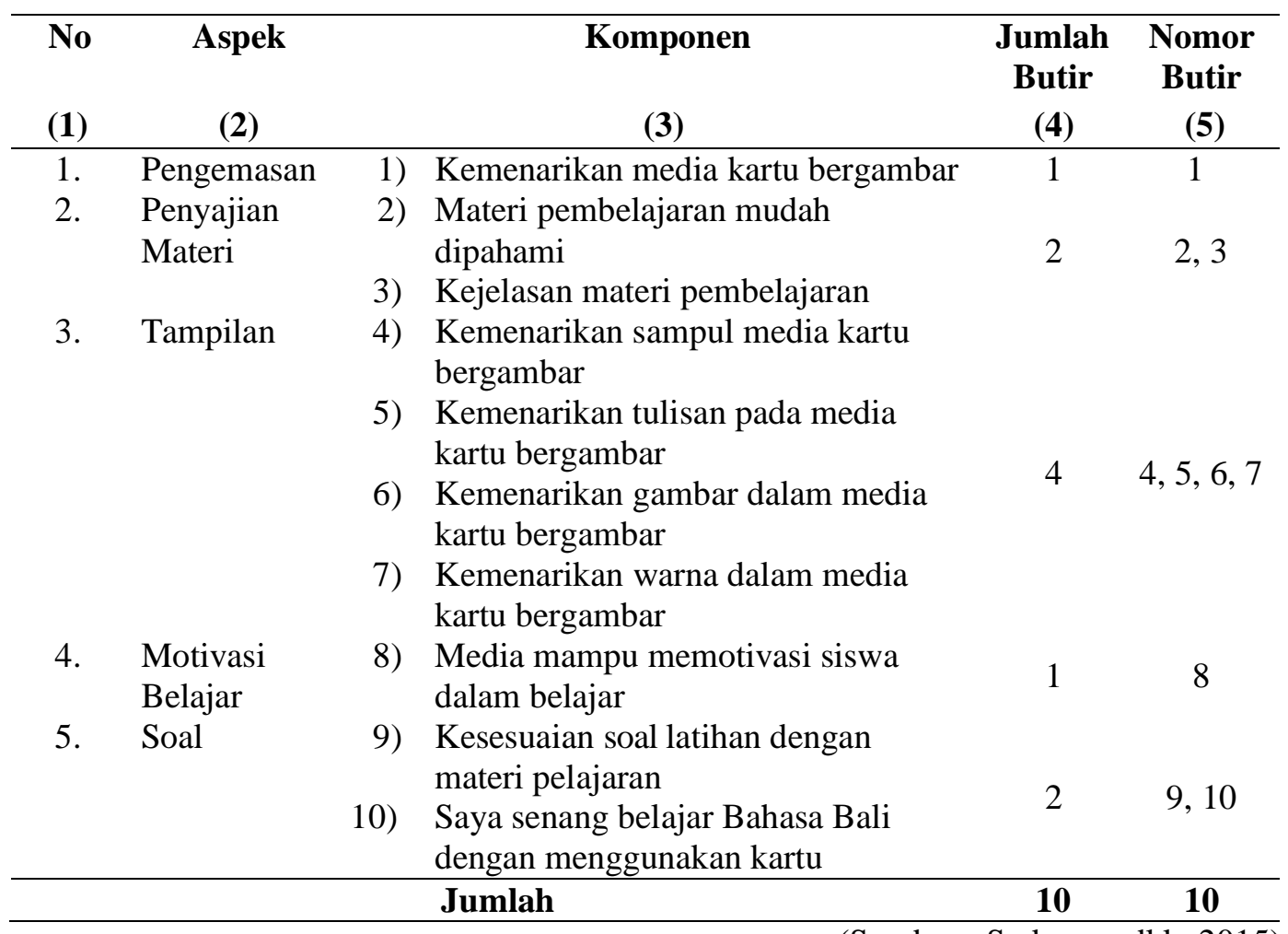

Tabel 5. Lembar Pedoman Wawancara

\begin{tabular}{|c|c|c|}
\hline No & Pertanyaan & Jawaban \\
\hline 1. & $\begin{array}{l}\text { Apakah Ibu ada kesulitan dalam } \\
\text { mengajar di kelas? }\end{array}$ & $\begin{array}{l}\text { Secara keseluruhan tidak terdapat } \\
\text { kesulitan namun, terkadang siswa } \\
\text { kurang terfokus dalam mengikuti } \\
\text { pembelajaran di kelas. }\end{array}$ \\
\hline 2. & $\begin{array}{l}\text { Apa saja media pembelajaran yang Ibu } \\
\text { gunakan saat proses pembelajaran? }\end{array}$ & $\begin{array}{l}\text { Media pembelajaran yang digunakan } \\
\text { hanya menggunakan kotak aksara }\end{array}$ \\
\hline 3. & $\begin{array}{l}\text { Apakah media pembelajaran tersebut } \\
\text { sudah mampu menarik perhatian siswa }\end{array}$ & $\begin{array}{l}\text { Sudah, namun masih ada beberapa } \\
\text { siswa yang kurang dalam kemampuan }\end{array}$ \\
\hline & $\begin{array}{l}\text { dan meningkatkan } \\
\text { pembelajaran di kelas? }\end{array}$ & $\begin{array}{l}\text { mengingat dan } \quad \text { memahami } \\
\text { pembelajaran }\end{array}$ \\
\hline 4. & Apakah siswa perlu belajar mandiri? & $\begin{array}{l}\text { Perlu karena siswa kelas } 3 \text { cenderung } \\
\text { lebih suka belajar sambil bermain }\end{array}$ \\
\hline 5. & $\begin{array}{l}\text { Media pembelajaran seperti apa yang } \\
\text { Ibu harapkan agar dapat membatu guru } \\
\text { dalam mencapai tujuan pembelajaran? }\end{array}$ & $\begin{array}{l}\text { Media yang mampu menarik minat } \\
\text { siswa dalam belajar, media yang } \\
\text { mampu memuat tujuan pembelajaran di } \\
\text { dalamnya, serta media yang bisa } \\
\text { bermain sambil belajar, dengan } \\
\text { demikian dapat meningkatkan hasil } \\
\text { belajar siswa karena siswa kelas } \\
\text { cenderung lebih senang belajar sambil } \\
\text { bermain. }\end{array}$ \\
\hline
\end{tabular}


Tabel 6. Lembar Pencatatan Dokumen

\begin{tabular}{|c|c|c|}
\hline No & Tahapan & Kegiatan \\
\hline 1. & Analisis & $\begin{array}{l}\text { 1. Wawancara dengan guru pengajar mata pelajaran Bahasa } \\
\text { Bali kelas III di SD Negeri } 4 \text { Kaliuntu yaitu Ibu Ni Made } \\
\text { Ayu Indra Wahyuni. S.Pd. B., dan observasi di kelas III } \\
\text { 2. Berdiskusi dengan guru mata pelajaran Bahasa Bali } \\
\text { mengenai penggunaan media dalam pembelajaran }\end{array}$ \\
\hline 2. & Desain & $\begin{array}{l}\text { 1. Menentukan KD dan Indikator } \\
\text { 2. Penentuan Model Pembelajaran } \\
\text { 3. Rancangan Media Kartu Bergambar } \\
\text { 4. Menyusun Instrumen Penilaian Media } \\
\text { 5. Menyusun Kisi-kisi soal dan butir soal } \\
\text { 6. Menyusun Kegiatan Pembelajaran }\end{array}$ \\
\hline 3. & Pengembangan & $\begin{array}{l}\text { 1. Pengembangan Media Kartu Bergambar dengan } \\
\text { menggunakan software corel draw } 2019 \\
\text { 2. Media Kartu Bergambar dikemas dalam bentuk media } \\
\text { cetak }\end{array}$ \\
\hline 5. & Implementasi & $\begin{array}{l}\text { 1. Melakukan uji efektivitas terhadap siswa dengan } \\
\text { memberikan pretest dan postest sehingga media kartu } \\
\text { bergambar dapat diketahui efektivitasnya dalam } \\
\text { meningkatkan hasil belajar siswa. }\end{array}$ \\
\hline 6. & Evaluasi & $\begin{array}{l}\text { 1. Produk media kartu bergambar berorientasi pendidikan } \\
\text { karakter ini di review oleh para ahli isi/mata pelajaran, } \\
\text { ahli desain pembelajaran, dan media pembelajaran. } \\
\text { Selain di review oleh para ahli, validitas produk media } \\
\text { kartu bergambar melibatkan siswa kelas VI untuk uji } \\
\text { coba perorangan dan uji coba kelompok kecil. Efektivitas } \\
\text { produk media kartu bergambar melibatkan siswa kelas III } \\
\text { untuk uji lapangan. }\end{array}$ \\
\hline
\end{tabular}

Metode analisis data yang digunakan dalam penelitian pengembangan ini yakni metode analisis deskriptif kualitatif, metode deskriptif kuantitatif, dan metode analisis statistik inferensial (uji-t). (1) Agung (2014:110) menjelaskan "metode analisis deskriptif kualitatif yaitu suatu cara analisis/pengolahan data dengan jalan menyusun secara sistematis dalam bentuk kalimat/kata-kata, kategori-kategori mengenai suatu objek (benda, gejala, variabel tertentu), sehingga akhirnya diperoleh kesimpulan umum". Metode analisis deskriptif kualitatif ini digunakan untuk menganalisis data yang berasal dari tanggapan, masukan, kritik, dan saran yang terdapat pada angket dan hasil wawancara. (2) Metode analisis deskriptif kuantitatif adalah "suatu cara pengolahan data yang dilakukan dengan cara menyusun secara sistematis dalam bentuk angka-angka dan atau presentasi, mengenai suatu objek yang diteliti, sehingga diperoleh kesimpulan umum" (Agung, 2014:110). Terkait dengan pemberian makna dan pengambilan keputusan menggunakan ketetapan sebagai berikut.

Tabel 7. Konversi Tingkat Pencapaian dengan Skala 5

\begin{tabular}{ccc}
\hline Tingkat & Kualifikasi & Keterangan \\
Pencapaian & Sangat baik & Tidak perlu direvisi \\
$90 \%-100 \%$ & Baik & Sedikit direvisi \\
$75 \%-89 \%$ & & \\
\hline
\end{tabular}




\begin{tabular}{ccc}
\hline $65 \%-74 \%$ & Cukup & Direvisi secukupnya \\
$55 \%-64 \%$ & Kurang & Banyak hal yang direvisi \\
$0-54 \%$ & Sangat Kurang & Diulangi membuat produk \\
\hline
\end{tabular}

(Sumber: Agung, 2014)

Metode analisis statistik inferensial (3) metode analisis statistik inferensial yakni "suatu cara pengolahan data yang dilakukan dengan jalan menerapkan rumus-rumus statistik inferensial untuk menguji suatu hipotesis penelitian yang diajukan peneliti, dan kesimpulan ditarik berdasarkan hasil pengujian terhadap hipotesis" (Agung, 2014:110). Analisis statistik inferensial digunakan guna menguji hipotesis dengan menganalisis data yang dihasilkan dari uji pretest dan posttest. Rumus yang digunakan dalam pengujian adalah uji-t berkorelasi (t-test). Penggunaan rumus uji-t berkorelasi ini didasari pada penggunaan dua perlakuan yang berbeda terhadap satu sampel. Sebelum uji hipotesis dilakukan data harus memenuhi prasyarat uji-t berkorelasi. Uji prasyarat tersebut yaitu uji normalitas dan homogenitas. (1) Uji normalitas dilakukan guna mengetahui sebaran skor pada setiap variabel berdistribusi normal atau tidak. Teknik Liliefors digunakan untuk menguji normalitas data. Sebaran data dikatakan berdistribusi normal, apabila selisih nilai yang terbesar lebih kecil dari kriteria nilai Liliefors. (2) Uji homogenitas ini dilakukan guna mencari tingkat kehomogenan secara dua pihak yang diambil dari kelompok-kelompok data terpisah dari satu sampel.

\section{HASIL DAN PEMBAHASAN}

\section{HASIL}

Rancang bangun media kartu bergambar menngacu pada kelima tahapan model ADDIE. Tahap pertama yakni tahap analisis. Tahap ini membutuhkan instrumen wawancara dan observasi yang digunakan untuk untuk menggali, mengetahui dan menganalisis dan kebutuhan dari peserta didik. Hasil analisis kebutuhan ditinjau dari analisis karakteristik siswa dan analisis fasilitas/lingkungan menunjukkan bahwa kurangnya media pembelajaran yang inovatif dalam proses pembelajaran.

Tahapan kedua yakni tahap desain. Adapun yang dilakukan pada tahap desain yakni (1) menentukan KD dan indikator, (2) Penentuan model pembelajaran mengacu pada karakteristik siswa dan media yang akan digunakan. Berkaitan dengan hal ini, Teams Games Tournament merupakan model pembelajaran yang tepat untuk disematkan dalam hal desain pelaksanaan pembelajaran dengan menggunakan media kartu bergambar ini. (3) Pembuatan desain visual. Proses ini bertujuan merancang tampilan serta tata letak konten media yang akan dikembangkan sesuai dengan kaidah desain penan pembelajaran. Hasil rancangan atau desain media Kartu Bergambar dibagi kedalam tiga bentuk yakni, (a) desain alat dan bahan, (b) prototype desain bentuk media, (c) dan desain petunjuk penggunaan; (4) Mempersiapkan instrumen kuisioner guna menunjang dan menggali informasi tentang kelayakan pengembangan media permainan kartu bergambar, (5) Penggunaan kisi-kisi sebagai acuan untuk membuat butir-butir soal, sebagai instrumen hasil belajar untuk menguji efektivitas media, (6) Mempersiapkan RPP. Adapun tujuan disusunnya RPP ini adalah untuk mengarahkan kegiatan pembelajaran pada peserta didik dengan menggunakan Media Kartu Bergambar berorientasi Pendidikan Karakter. 
Tahapan ketiga yang dilakukan adalah tahap pengembangan. Tahap pengembangan dibagi menjadi tiga tahapan, yakni: (1) Pengembangan kemasan, (2) pengembagan media kartu bergambar, dan (3) pengembangan petunjuk penggunaan media.

Tahapan keempat yang dilakukan adalah tahap implementasi media setelah melalui proses tahapan analisis, desain, dan pengembangan. Adapun hal yang dilakukan dalam tahap implementasi produk meliputi: (1) Uji validasi media kartu berdasarkan aspek media oleh ahli media pembelajaran, (2) Uji validasi media kartu berdasarkan aspek desain pembelajaran oleh ahli desain pembelajaran, (3) Uji validasi media kartu berdasarkan aspek isi mata pelajaran, (4) uji coba perorangan, (5) uji coba kelompok kecil, dan (6) uji lapangan. Tahapan terakhir yang dilakukan adalah tahap evaluasi, bertujuan guna memvalidasi dan mengukur efektivitas media yang telah dibuat. Uji validasi bertujuan guna menguji media yang sudah dibuat, sementara uji efektivitas bertujuan guna mengukur tingkat efektivitas produk yang dibuat. Dengan demikian dalam penelitian ini, media kartu bergambar sudah berhasil dikembangkan dengan menggunakan model ADDIE.

Uji validitas media kartu bergambar bertujuan untuk menguji tingkat kelayakan produk. Penilaian oleh para ahli dilakukan dengan melibatkan teknolog pembelajaran dan dosen yang berkompeten dibidang konten pembelajaran. Instrumen pengembangan kartu bergambar ini berupa kuesioner yang telah dipersiapkan sebelumnya yang bertujuan guna mengetahui validitas produk. Instrumen tersebut terlebih dahulu diuji validitas butirnya oleh tiga orang dosen yang berkompeten. Pada validitas isi mata pelajaran diperoleh hasil 1 dengan kualifikasi sangat tinggi, validitas desain pembelajaran diperoleh hasil 0,84 dengan kualifikasi sangat tinggi, validitas media pembelajaran diperoleh hasil 1 dengan kualifikasi sangat tinggi, serta validitas siswa diperoleh hasil 0,90 dengan kualifikasi sangat tinggi. Adapun hasil validasi instrumen yang telah diuji, dapat disajikan pada tabel 8 .

Tabel 8. Hasil Uji Validitas Instrumen

\begin{tabular}{ccc}
\hline Jenis Validitas & Hasil & Kualifikasi \\
\hline Validitas Isi & 1 & Sangat tinggi \\
Validitas Desain & 0,84 & Sangat tinggi \\
Validitas Media & 1 & Sangat tinggi \\
Validitas Siswa & 0,90 & Sangat tinggi \\
\hline
\end{tabular}

Penilaian oleh teknolog pembelajaran berkaitan dengan validitas media dan desain pembelajaran, sedangkan uji coba oleh dosen berkenaan dengan konten yang ada dalam media. Hasil validitas pengembangan media kartu bergambar menurut ahli isi mata pelajaran, ahli desain pembelajaran, ahli media pembelajaran, serta subyek uji coba perorangan, serta uji coba kelompok kecil secara lebih rinci pada tabel 9.

Tabel 9. Hasil Uji Validitas Produk

\begin{tabular}{clcl}
\hline No & Subjek Uji Coba $\boldsymbol{E}$-Modul & Hasil Validitas (\%) & Keterangan \\
\hline 1. & Uji Ahli Isi Mata Pelajaran & $100 \%$ & Sangat Baik \\
2. & Uji Ahli Desain Pembelajaran & $95,71 \%$ & Sangat Baik \\
3. & Uji Ahli Media Pembelajaran & $95,00 \%$ & Sangat Baik \\
4. & Uji Coba Perorangan & $97,33 \%$ & Sangat Baik \\
5. & Uji Coba Kelompok Kecil & $97,55 \%$ & Sangat Baik \\
\hline
\end{tabular}

Berdasarkan pengujian yang dilakukan oleh ahli media diperoleh persentase tingkat pencapaian sebesar 95,00\% dengan kualifikasi sangat baik, pengujian oleh ahli desain 
diperoleh persentase tingkat pencapaian sebesar 95,71\% dengan kualifikasi sangat baik, pengujian oleh ahli materi diperoleh persentase tingkat pencapaian sebesar $100 \%$. Berdasarkan uji coba perorangan yang dilakukan oleh 3 (tiga) orang siswa kelas III di SD Negeri 4 Kaliuntu diperoleh persentase tingkat pencapaian sebesar 97,33\% dengan kualifikasi sangat baik, serta berdasarkan uji coba kelompok kecil yang dilakukan oleh 9 (tiga) orang siswa kelas III di SD Negeri 4 Kaliuntu diperoleh persentase tingkat pencapaian sebesar 97,55\% dengan kualifikasi sangat baik. Dari hasil tersebut diperoleh kesimpulan bahwa media kartu bergambar layak untuk digunakan tanpa revisi. Efektivitas media sederhana kotak hitung dianalisis dengan membandingkan skor tes sebelum media diterapkan dalam pembelajaran (pretest) dan sesudah media diterapkan dalam pembelajaran (posttest) dengan rumus uji t. Subjek yang digunakan yakni seluruh siswa kelas III di SD Negeri 4 Kaliuntu dengan jumlah 30 orang. Sebelum dilakukan Uji t, data pretest dan posttest dianalisis normalitas dan homogenitasnya. Data dikatakan berdistribusi normal apabila hasil perhitungan (L0) lebih kecil dari kriterium (Ltabel).

Adapun hasil pengembangan produk media kartu bergambar berorientasi pendidikan karakter, dapat disajikan dalam gambar 1 dan 2.
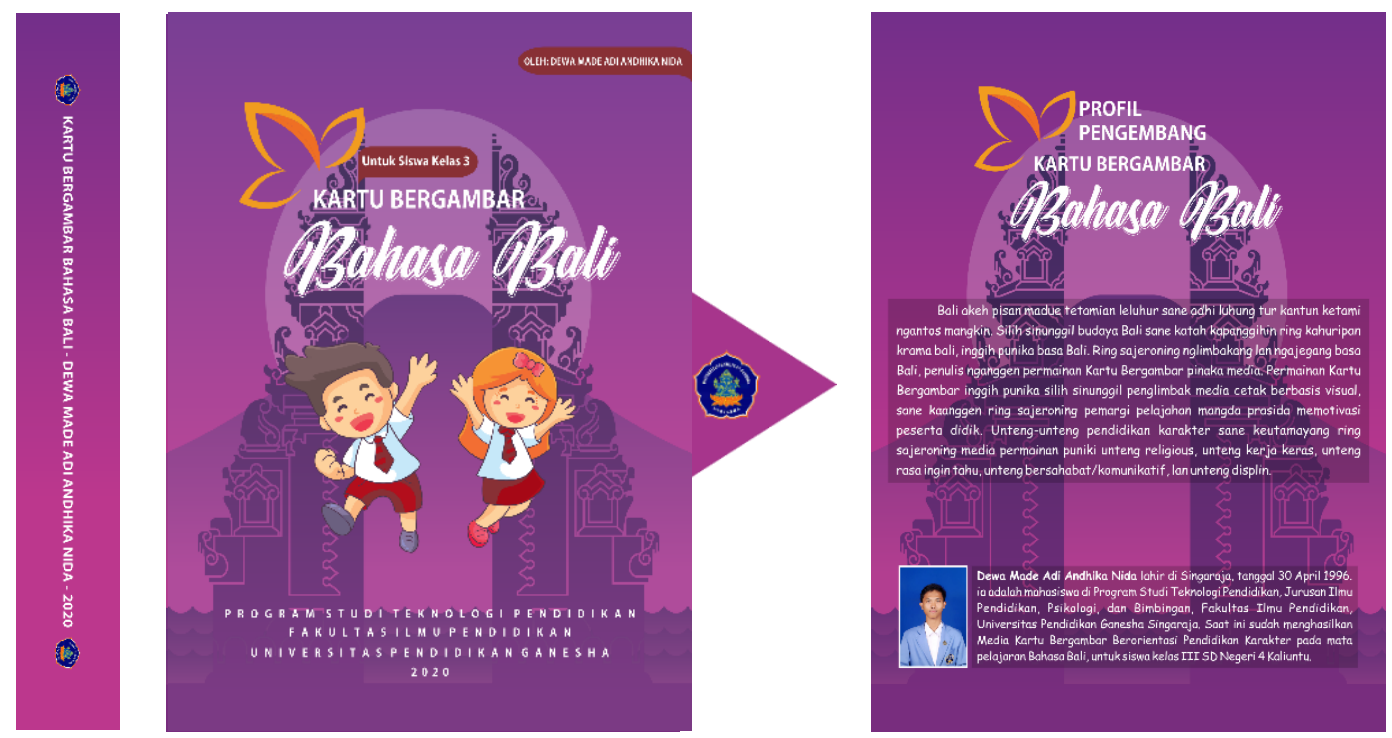

Gambar 1. Kemasan Media Kartu Bergambar
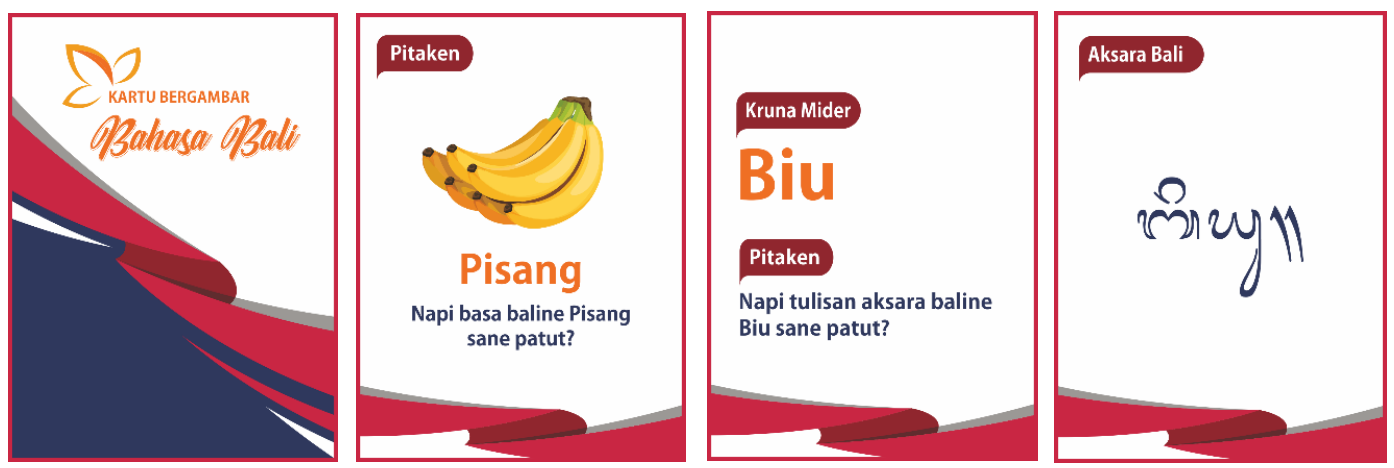

Gambar 2. Kartu Bergambar 
Tabel 10. Hasil Normalitas dan Homogenitas Pretest dan Posttest

\begin{tabular}{ccccccc}
\hline No & Hasil Belajar & $\mathbf{L}_{\mathbf{0}}$ & $\mathbf{L}_{\mathbf{t}}$ & Keterangan & Varians & Keterangan \\
\hline 1. & Pretest & 0,1348 & 0,1590 & Normal & 172,9 & Homogen \\
2. & Posttest & 0,1364 & 0,1590 & Normal & 110,9 & Homogen \\
\hline
\end{tabular}

Berdasarkan perhitungan yang dilakukan diperoleh hasil L0 Pretest $=0,1348, \mathrm{~L} 0$ Posttest $=0,1364$, Ltabel pada taraf signifikansi 5\%. Ini berarti harga L0 lebih kecil dari harga L tabel pada taraf signifikansi 5\% (L0 < Ltabel). Dengan demikian diperoleh kesimpulan maka sampel berasal dari populasi yang berdistribusi normal. Selanjutnya, pada uji homogeitas, data dikatakan homogen apabila hasil perhitungan (Fhitung) lebih kecil dari kriterium (Ftabel). Hasil uji homogenitas pretest dan posttest, dapat disajikan pada tabel 5 .

Berdasarkan hasil perhitungan diketahui harga Fhitung $=1,6$ dan Ftabel pada taraf signifikansi $5 \%=4,2$. Ini berarti harga Fhitung lebih kecil dari < harga Ftabel pada taraf signifikansi 5\% (Fhitung< Ftabel). Dengan demikian diperoleh kesimpulan varian kelompok homogen. Jadi dari hasil perhitungan, didapatkan varians pretest 172,9 dan varians posttest 110,9 .

Setelah prasyarat uji analisis data terpenuhi, maka dilakukan uji t. Media dapat dikatakan efektif apabila hasil thitung lebih besar dari ttabel (thitung > ttabel). Berdasarkan hasil perhitungan diperoleh hasil thitung $=27,80$ dan ttabel $=1,671$. Ini berarti thitung lebih besar dari ttabel (thitung>ttabel) sehingga dapat disimpulkan media kartu bergambar efektif untuk meningkatkan hasil belajar siswa kelas III di SD Negeri 4 Kaliuntu pada mata pelajaran Bahasa Bali.

\section{PEMBAHASAN}

Berdasarkan uji efektivitas yang telah dilakukan terbukti bahwa media kartu bergambar beriroentasi pendidikan karakter efektif diterapkan untuk meningkatkan hasil belajar siswa. Serangkaian proses yang dilewati dari semua tahap pengembangan media berdasarkan model ADDIE yang berimplikasi pada keefektifan media mulai dari analisis, perancangan, pengembangan serta uji coba dan perbaikan yang menunjang keberhasilan pengembangan media kartu bergambar berorientasi pendidikan karakter benar-benar mampu meyakinkan bahwa media kartu ini layak digunakan dalam proses pembelajaran.

Dengan adanya media kartu bergambar berorientasi pendidikan karakter, siswa dapat belajar dengan mudah karena kartu dilengkapi dengan adanya gambar, dan teks yang mampu menarik perhatian siswa. Di samping itu, siswa juga lebih partisipatif dalam proses pembelajaran. Bagi pihak guru, adanya media kartu bergambar ini lebih memudahkan guru dalam pelaksanaan proses pembelajaran didalamnya dilengkapi dengan petunjuk penggunaan media, SK, KD, indikator, dan tujuan pembelajaran, serta nilai-nilai pendidikan karakter yang harus dicapai siswa dalam proses pembelajaran.

Berdasarkan pengkajian lebih lanjut, ada beberapa aspek penting yang berpengaruh pada efektivitas media yang dikembangkan terhadap hasil belajar siswa. Aspek tersebut yakni aspek konten pembelajaran, desain pembelajaran, dan media pembelajaran.

Ditinjau dari aspek konten pembelajaran, informasi kompetensi dasar, indikator, tujuan pembelajaran, serta petunjuk belajar pada media kartu bergambar tersedia dengan jelas. Ketersediaan informasi tersebut dapat dilihat dari tersedianya informasi tersebut dalam kemasan media kartu bergambar, dengan tujuan agar mempermudah siswa dalam 
memetakan materi pembelajaran, agar proses pencapaian tujuan pembelajaran efektif. Berkaitan dengan hal ini, Sanjaya (2008) menjelaskan bahwa "perencanaan pembelajaran merupakan sebuah proses penerjemahan kurikulum menjadi program-program pembelajaran yang dijadikan pedoman oleh guru dalam proses pembelajaran agar pembelajaran efektif". Dari pernyataan ini nampak jelas bahwa pedoman belajar sangatlah diperlukan untuk mengefektifkan penyampaian informasi pembelajaran.

Ditinjau dari kebahasan, tata bahasa dalam media kartu bergambar tergolong sudah tepat yang nampak dari teks pada media yang menggunakan kata, kalimat, dan tanda baca yang baik sesuai dengan Ejaan Bahasa Indonesia Yang Disempurnakan (EYD) serta merujuk pada karakteristik siswa agar tulisan mudah dimengerti. Terkait dengan pengaruh tata bahasa dalam media kartu bergambar guna menunjang kefektifan proses pembelajaran, Jaya \& Suyanto (2016) menjelaskan bahwa "ragam bahasa yang baik adalah bahasa yang menggunakan variasi huruf, kata, dan tanda baca, dengan tujuan agar mempermudah pembaca memahami maksud dan tujuan dari kalimat atau kata yang dibaca".

Selanjutnya, Kejelasan petunjuk pengerjaan soal latihan yang tergolong baik. kejelasan petunjuk ini bermuara pada kejelasan dalam pengerjaan soal sehingga meminimalisir kendala dalam pengerjaan soal latihan yang diberikan. Petunjuk pengerjaan soal, berfungsi untuk membantu siswa dalam mengerjakan soal. Disamping petunjuk, karakteristik soal juga turut berperan penting. Jenis soal latihan yang digunakan adalah tipe pilihan ganda (multiple choice) dan tipe bentuk melengkapi (completion). Tipe ini dipilih karena tes objektif mampu mencakup materi pembelajaran secara kompleks. Tes obyektif yang disematkan pada media tergolong sesuai dengan materi yang disajikan dalam media. Koyan (2012) menjelaskan bahwa "tes objektif memiliki persyaratan tes yang baik, diantaranya dapat dilihat dari segi objektivitas, reliabilitas, dan daya beda antara siswa yang berhasil dengan siswa yang gagal atau kurang". Soal latihan yang dibuat sudah memiliki tingkat kesulitan yang dapat dikatakan sesuai, kesesuaian tersebut dapat dilihat dari hasil perhitungan taraf kesukaran butir tes, bahwa beberapa soal memiliki taraf yang mudah dan sedang, serta merujuk pada karakteristik siswa agar siswa mudah dalam mengerjakan soal. Hal tersebut sejalan dengan pendapat Sanjaya (2008) menjelaskan bahwa "tes disusun untuk mengumpulkan informasi mengenai penguasaan materi pembelajaran, serta tes yang standar harus memiliki tingkat kesulitan dan daya beda yang baik". Selain itu, soal latihan yang dibuat sudah sesuai dengan indikator dan tujuan pembelajaran. hal tersebut dapat dilihat dari instrumen kisi-kisi butir soal yang dibuat. Terkait hal tersebut, Sanjaya (2008) menjelaskan bahwa "setiap desainer pembelajaran harus mampu merumuskan tes sesuai dengan tujuan pembelajaran, guna menentukan indikator keberhasilan serta berfungsi untuk mengecek ketepatan dari rumusan tujuan pembelajaran".

Ditinjau dari aspek desain pembelajaran, Kefektifan penerapan media kartu bergambar dipengaruhi banyak hal. Materi pembelajaran yang digunakan mengacu pada standar kompetensi, tujuan pembelajaran, serta berpedoman pada buku ajar "Basa Lan Sastra Bali" yang digunakan oleh guru Bahasa Bali kelas III di SD Negeri 4 Kaliuntu. Pada dasarnya materi yang baik harus sesuai dengan tujuan pembelajaran, agar siswa mudah dalam memetakan materi pembelajaran. Gafur (2012) menjelaskan bahwa "cara yang tepat digunakan untuk memilih materi pembelajaran adalah dengan memperhatikan standar kompetensi pembelajaran, serta tujuan pembelajaran, disamping itu buku-buku teks juga merupakan sumber utama dalam menentukan materi pembelajaran yang akan digunakan". Keberhasilan Media kartu bergambar dalam meningkatkan hasil belajar juga dikarenakan 
oleh kemampuanya dalam merangsang siswa untuk aktif. Hal tersebut dapat dilihat pada saat penerapan media, siswa sangat aktif dalam bermain, dan bekerja sama dengan anggota kelompoknya untuk menyelesaikan pertanyaan yang terdapat pada kartu. Media juga mampu menambah semangat belajar siswa. Selain itu, terungkap bahwa media kartu bergambar mampu memotivasi siswa dalam belajar serta membuat pembelajaran bahasa Bali menjadi lebih menarik. Terkait hal tersebut, Sudjana dan Riva'i (dalam Kustandi \& B.S., 2016) menjelaskan bahwa "media pembelajaran mampu menarik perhatian siswa, sehingga mampu menumbuhkan motivasi belajar".

Kesesuaian media kartu bergambar dengan karakteristik siswa kelas III di SD Negeri 4 Kaliuntu juga turut ambil andil dalam kefektifan media. Siswa lebih mudah memahami pelajaran setelah guru menggunakan media pembelajaran, siswa merasa senang belajar sambil bermain, siswa juga merasa senang ketika belajar menggunakan media. Hal ini dikarenakan oleh siswa yang lebih senang belajar jika materi disertai dengan contoh gambar yang mendukung. Gambar dalam media kartu bergambar tergolong jelas, karena gambar yang digunakan adalah gambar vektor yang telah melalui tahap trace, agar gambar sesuai dengan gambar aslinya. Gambar yang jelas dapat membantu siswa dalam menjawab pertanyaan yang terdapat dalam kartu bergambar. Hal tersebut sejalan dengan pendapat Sudarma, dkk (2015) menjelaskan bahwa "gambar sangat membantu pembelajar memahami pesan yang ingin disampaikan, pilihlah gambar yang sederhana dan berikan keterangan pada gambar agar tidak terjadi salah persepsi”. Tulisan atau font dalam media kartu bergambar dapat dikatakan jelas, karena jenis font yang digunakan adalah Sans Serif yakni “Adobe Gothic Std B" dengan ukuran 15 point dan 30 point, font ini dipilih karena memiliki ketebalan yang sama, serta ukuran font yang dipilih sudah disesuaikan dengan ukuran ruang yang tersedia pada kartu, sehingga memudahkan siswa dalam membaca tulisan yang terdapat pada kartu. Hal tersebut sejalan dengan pendapat Sriwitari \& Widnyana (2014) menjelaskan bahwa "huruf Sans Serif memiliki bagian tubuh yang sama tebalnya, sehingga efektif digunakan dalam penulisan teks pendek serta memiliki keterbacaan yang jelas".

Ditinjau dari aspek media pembelajaran, desain sampul kemasan media kartu bergambar pada bagian depan dan belakang dapat dikatakan menarik, hal tersebut dapat dilihat dari proses pembuatan sampul media menggunakan prinsip-prinsip desain pesan. Penggunaan warna pada sampul kemasan media, menggunakan warna dasar Ungu, pemilihan warna Ungu mengacu pada karakteristik warna sebagai penunjuk produk dalam buku prinsip desain pesan, serta kemasan yang menarik, dapat menarik perhatian dan minat siswa dalam menggunakan media kartu bergambar. Hal tersebut sejalan dengan pendapat Pujiyanto (dalam Sudarma, dkk, 2015) menjelaskan bahwa "warna Ungu memiliki kesan yang manis dalam sebuah produk, sehingga media mampu menarik perhatian siswa dalam menggunakan media kartu bergambar". Penempatan gambar dan teks dalam sampul kemasan bagian depan dan belakang dapat dikatakan seimbang, karena penempatan gambar serta teks yang baik dan seimbang mampu menarik perhatian, serta memudahkan siswa pada saat menggunakan media kartu bergambar. Hal tersebut sejalan dengan pendapat Sriwitari \& Widnyana (2014) menjelaskan bahwa "desain dapat dikatakan seimbang apabila penempatan objek pada bagian kiri, kanan, atas, dan bawah setara sehingga terkesan stabil". Penyajian gambar dalam media kartu dapat dikatakan tepat dengan materi pembelajaran, karena gambar yang digunakan sudah sesuai dan mewakili isi pesan yang terkandung dalam materi pembelajaran. Hal tersebut sejalan dengan pendapat 
Sudarma, dkk (2015) menjelaskan bahwa "penyajian gambar sangat memberikan manfaat yang berarti kepada pembaca, karena kejelasan pada gambar sangat mendukung pesan yang terkandung dalam teks". Pemilihan warna teks dengan background dapat dikatakan tepat, karena warna teks dengan background kontras, yakni warna teks yang digunakan adalah warna biru dan orange, sedangkan warna background menggunakan warna putih, sehingga dapat dikatakan tepat, pemilihan warna juga mengacu pada karakteristik siswa yakni, warna yang kontras akan mempermudah siswa dalam memahami isi pesan dalam kartu bergambar. Hal tersebut sejalan dengan pendapat Sriwitari \& Widnyana (2014) menjelaskan bahwa "kekuatan warna sangat dipengaruhi oleh background, penggunaan warna kontras akan membuat teks lebih hidup". Tata letak gambar dan teks dapat dikatakan tepat, karena dalam desain kartu, gambar dan teks diletakkan secara vertikal atau dari atas ke bawah, agar memberikan kemudahan bagi siswa dalam menjawab pertanyaan. Hal tersebut sejalan dengan pendapat Sudarma, dkk (2015) menjelaskan bahwa "gambar dapat membantu siswa dalam memahami maksud dari pesan yang disampaikan melalui teks". Ketahanan dan kualitas media kartu bergambar dapat dikatakan baik, hal tersebut dapat dilihat dari bahan-bahan yang digunakan dalam pembuatan kotak kemasan dan kartu bergambar. Kotak kemasan dibuat dengan menggunakan kertas karton, berukuran tebal yang direkatkan dengan menggunakan lem G, dan kemudian dilapisi dengan desain sampul yang dicetak menggunakan kertas stiker yang dilaminasi glossy dengan tujuan agar kotak kemasan tahan lama. Kemudian kartu bergambar dicetak dengan menggunakan kertas Art Paper yang dilaminasi Doff agar kartu tidak mudah rusak.

\section{SIMPULAN}

Terdapat 3 hal yang dapat disimpulkan agar media kartu bergambar berorientasi pendidikan karakter dapat digunakan untuk menunjang keberhasilan pembelajaran siswa takni pertimbangan rancang bangun produk yang mana rancang bangun media kartu bergambar berorientasi pendidikan karakter dikembangkan berdasarkan model ADDIE yaitu: (a) tahap analisis (analysis), (b) tahap desain (design), (c) tahap pengembangan (development), (d) tahap implemetasi (implementation), dan (e) tahap evaluasi (evaluation). Selanjutnya agar dapat digunakan untuk menunjang proses pembelajaran maka media kartu bergambar berorientasi pendidikan karakter harus melewati tahap uji vaidasi yang terdiri dari uji validasi ahli (ahli isi, media pembelajaran, ahli desain pembelajaran) serta uji coba produk (uji perorangan, dan uji kelompok kecil) yang mana ketiga ahli memberikan penilaian sangat baik (valid) serta respon siswa subjek siswa perorangan dan kelompok kecil yang tergolong sangat baik (valid), dengan tetap melakukan revisi sesuai dengan masukan, komentar, dan saran. Tahap terakhir adalah uji efektifitas yang mana berdasarkan pengujian dengan uji-t berdasarkan nilai pretest dan posttest yang telah dilakukan, terbukti bahwa media kartu bergambar berorientasi pendidikan karakter efektif diterapkan untuk meningkatkan hasil belajar siswa kelas III di SD Negeri 4 Kaliuntu pada mata pelajaran Bahasa Bali materi aksara Bali.

\section{DAFTAR PUSTAKA}

Agung, A. A. G. (2014). Buku Ajar Metodelogi Penelitian Pendidikan. Yogyakarta: Aditya Media Publishing.

Ariyanti dan I. M. Z. (2015). Efektivitas Alat Permainan Edukatif (APE) Berbasis Media Dalam Meningkatkan Kemampuan Berhitung Pada Anak Kelas 2 Di SDN 2 
Wonotirto Bulu Temanggung. Jurnal IKA, 11(1), 12-26.

Asyhar, R. (2012). Kreatif Mengembangkan Media Pembelajaran. Jakarta: Refrensi Jakarta.

Gafur, A. (2012). Desain Pembelajaran Konsep, Model, dan Aplikasinya dalam Perencanaan Pelaksanaan Pembelajaran. Yogyakarta: Penerbit Ombak.

Hidayati, Abna, dkk. (2014). The Development Of Character Education Curriculum For Elementary Student In West Sumatera. International Journal of Education and Research, 2(6), 189-198.

Hijriati. (2017). Peranan dan Manfaat APE untuk Mendukung Kreativitas Anak Usia Dini. Dosen PAUD FKIP Unsyiah Banda Aceh, III(2), 59-69.

Jamuna dan Pankajam. (2017). Utilization Of Instructional Media In Teaching Science. International Journal of Research Granthaalayah, 5(3), 51-56.

Jaya, N.P., E. Suyanto. (2016). Pemakaian Bahasa Pada Surat Pengumuman Formal di Lingkungan Universitas Lampung. Jurnal Kata (Bahasa, Sastra, Dan Pembelajarannya), 1-12.

Koyan. (2012). Statistik Pendidikan Teknik Analisis Data Kuantitatif. Singaraja: Universitas Pendidikan Ganesha Press.

Kustandi, Cecep dan B. S. (2016). Media Pembelajaran Manual dan Digital. Jakarta: Ghalia Indonesia.

Mardati, Asih dan M.N., Wangit. (2015). Pengembangan Media Permainan Kartu Gambar Dengan Teknik Make A Match Untuk Kelas 1 SD. Jurnal Prima Edukasia, 3(2), 120132.

Martini, D. (2018). Pengembangan Wayang Tokoh Dongeng Berbasis Pendidikan Karakter pada Pelajaran Bahasa Bali Kelas III Sekolah Dasar. Jurnal EDUTECH Universitas Pendidikan Ganesha, 6(1), 77-88.

Meiliani, Y. N. (2017). Pengaruh Metode Permainan Media Kartu Kuartet Terhadap Hasil Belajar Siswa Sub Materi Vertebrata. Jurnal Keguruan Dan Ilmu Pendidikan, 1(2), 49-54.

Pertama, P.P.G.P., dkk. (2015). Pengembangan Aplikasi Mobile Pengenalan Aksara Bali Ke Dalam Huruf Latin Dengan Augmented Reality. Jurnal Seminar Nasional Teknologi Informasi Dan Komunikasi, 237-243.

Pradipta, I.B.Y.S., dan I. G. M. Darmawiguna. (2015). Pengembangan Aplikasi Game Basa Bali Sebagai Media Pembelajaran Bahasa Bali Berbasis Android. Kumpulan Artikel Mahasiswa Pendidikan Teknik Informatika, 4(5).

Prasetya, Y.K., dan S. Khabibah. (2016). Pengembangan Media Permainan Kartu Kwartet Dalam Pembelajaran Matematika Pada Materi Pokok Segitiga Dan Segiempat. Jurnal Ilmiah Pendidikan Matematika, 1(5), 95-101.

Rahayu, dkk. (2017). Implementation of Character Education Through Culture 5S (Senyum, Sapa, Salam, Sopan, dan Santun) at State Junior High School 2 Ngawi (SMPN 2 Ngawi) East Java Indonesia. International Research-Based Education Journal, 1(2), 130-135.

Sanjaya, W. (2008). Perencanaan dan Desain Sistem Pembelajaran. Jakarta: Kencana Prenada Media Group.

Setiawati, N. A. (2017). Pendidikan Karakter Sebagai Pilar Pembentukan Karakter Bangsa. 1(1), 350. 
Sriwitari, N.Y., dan I.G.N., Widnyana. (2014). Desain Komunikasi Visual. Yogyakarta: Graha Ilmu.

Sudarma, I.K., dkk. (2015). Desain Pesan Kajian Analisis Desain Visual Teks dan Image. Yogyakarta: Graha Ilmu.

Sujana, W. (2017). Pembelajaran Sor Singgih Bahasa Bali Dalam Keterampilan Berbicara Di Kelas VII SMP Negeri 1 Tabanan Tahun Pelajaran 2016/2017. Jurnal Ilmiah Pendidikan Dan Pembelajaran, 1(1), 48-56.

Tegeh, I.M., dkk. (2015). Pengembangan Buku Ajar Model Penelitian Pengembangan Dengan Model ADDIE. http://webcache.googleusercontent.com/search?q=cache:yuBE7FUnNgJ:eproceeding.undiksha.ac.id/index.php/senari/article/download/507/352/+\& cd=6\& (diakses 29 April 2019).

Zubaedi. (2011). Desain Pendidikan Karakter. Jakarta: Kencana Prenada Media Group. 